\title{
浚渫窪地における導水を用いた貧酸素改善に関する検討

\author{
Numerical Study on Effective Measures Using Water Duct for Reducing Anoxia \\ in a Dredged Trench in Coastal Waters
}

\author{
吉本侑矢 ${ }^{1}$. 佐々木 淳 $^{2}$.下迫健一郎 ${ }^{3} \cdot$ 木村俊介 ${ }^{4}$ \\ Yuya YOSHIMOTO, Jun SASAKI, Kenichiro SHIMOSAKO and Shunsuke KIMURA
}

\begin{abstract}
To consider effective measures using water duct for reducing anoxia in coastal dreaged trenches, we first developed a water quality model including dissolved oxygen and sufide processes copuled with hydrodynamic model using MIKE3 and ECO Lab (DHI).The model was applied to reproduce water quality processes in dredged trenches with one-way nesting approach and verified through comparison with measured data.Peforming numerical experiments installing water duct and transporting oxygen rich water to the bottom, we showed that transport of surface water with less dense is effective and more practical for the present purpose.
\end{abstract}

\section{1. はじめに}

東京湾の閉鎖性水域に点在する浚渫窪地においては初 夏から晚秋にかけて無酸素水塊が発生し, その湧昇によ って青潮が発生する等, 重大な水質問題となっている （佐々木ら，1996）。洨渫窪地に関する対策としては, 窪 地の埋め戻しが有力な手段と考えられ, 一部では埋め戻 し事業が実施されているが, 現状では数十年スケールの 長期的な取り組みが必要である（大見ら，2008；中村ら， 2008). 一方, 冬季の浚渫窪地においては酸素が回復し, よい漁場として活用されていることから, 導水等の水工 学的手法で酸素を回復させ, 窪地を有効利用するのも一 つの方策であると考えられるが，本手法の有効性に関す る定量的な検討は行われていない. そこで本研究では浚 渫窪地問題の解決方策の一つとして, 導水技術を用いた 無酸素水の改善方策について定量的な検討を行うことを 目的とする.

研究手法としては我が国における最大規模の洨渫窪地 である, 東京湾幕張沖の浚渫窪地に着目し, 現地調査に よる硫化物動態を把握する。また, 溶存酸素濃度（DO） と硫化物を従属変数に含む 3 次元水質モデルを構築し, 現地調査結果との比較を通して, 浚渫窪地内の水質変動 を再現可能な数值予測手法を確立する．次に，開発した 数值モデルを用い, 導水による浚渫窪地の水質改善手法 に関する数值実験を行うことで, 有効な方策について検 討する.

\begin{tabular}{|c|c|c|}
\hline & 修 (工) & 高知県 \\
\hline 正会員 & 博 (工) & 横浜国立大学教授大学院工学研究院 \\
\hline 正会員 & 博 (工) & $\begin{array}{l}\text { 国土交通省関東地方整備局横浜港湾空港技 } \\
\text { 術調查事務所長 }\end{array}$ \\
\hline & & $\begin{array}{l}\text { 国土交通省関東地方整備局横浜港湾空港 } \\
\text { 技術調查事務所調査課長 }\end{array}$ \\
\hline
\end{tabular}

\section{2. 方法}

東京湾幕張沖浚渫窪地を対象とし, DOおよび硫化物 を含む水質場の再現を目的とした数值モデルを構築する.

モデルにはデンマーク水理環境研究所（DHI）で開発 されたMIKE3の準3次元流動モデルを採用し, 水質モデ ルに関してはECO Lab機能を用いて開発する. 本モデル を 2007 年の東京湾全域 (大領域) に適用し, 次いでoneway ネスティングにより, 浚渫窪地を含む湾奥部小領域 の詳細再現計算を行う. 本計算結果を現地調査結果と比 較することにより, 数值モデルの妥当性を検証した後, 本モデルに導水過程を組み込み, 2007 年 8 月の 1 ケ月を 対象とした数值実験を行う.

\section{（1）流動モデル}

DHIの準 3 次元バージョンのMIKE3Dを用い, 水平方 向には正方形格子, 鉛直方向には $z$ 座標モデルを採用

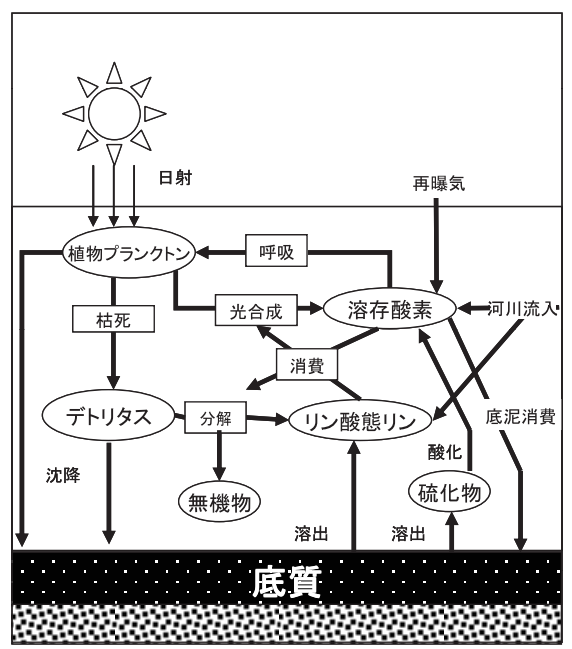

図-1 水質モデルの概要 
した。

渦動粘性・拡散係数に関しては, 水平方向には Smagorinskyモデル，鉛直方向には標準 $k-\varepsilon$ モデルを採 用した。

\section{（2）水質モデル}

DHIのECO Labを用い，植物プランクトン $C_{P P L}$, 懸濁 態有機物 $C_{D E T}$, 溶存無機態リン $C_{P O 4}, \mathrm{DO} C_{D O}$, 硫化物 $C_{\text {sul }}$, および底質中有機物 $B_{\text {sed }}$ それぞれの濃度を従属変数 として採用し，佐々木ら（1998），田中ら（1997），中村 ら（2008）を参考に，図-19諸過程を考慮した数值モデ ルを構築した。各従属変数は基本的には移流・拡散過程 に従うものとし，生成項については以下のようにモデル 化した。

$$
\begin{aligned}
& \frac{d C_{P P L}}{d t}=(\text { 光合成による增殖 })-(\text { 呼吸 })-(\text { 枯死 })-(\text { 沈降 }) \\
& \frac{d C_{D E T}}{d t}=(\text { 植物プランクトンの枯死 })-(\text { 沈降 }) \\
& \quad-(\text { 好気的無機化による消費 }) \\
& \quad-(\text { 嫌気的無機化による消費 })
\end{aligned}
$$

$$
\begin{aligned}
& \frac{d C_{P O_{4}}}{d t}=-(\text { 植物プランクトンによる摂取 }) \\
& \quad+(\text { 植物プランクトンの呼吸による回帰 }) \\
& \quad+(\text { 懸濁態有機物の無機化による回帰 }) \\
& \quad+(\text { 底泥からの溶出 })
\end{aligned}
$$

$$
\begin{aligned}
& \frac{d C_{D O}}{d t}=(\text { 光合成による生産 })+(\text { 再曝気 }) \\
& -(\text { 植物プランクトンによる消費 }) \\
& \quad-(\text { 懸濁態有機物の無機化による消費 }) \\
& \quad-(\text { (゙ックグラウンドの消費 }) \\
& \quad-(\text { 底泥での消費 })-(\text { 硫化物の酸化による消費 })
\end{aligned}
$$$$
\begin{aligned}
& \frac{d C_{s u l}}{d t}=(\text { 底質の嫌気的無機化による生成 }) \\
& \quad+(\text { 懸濁態有機物の嫌気的無機化による生成 }) \\
& \quad-(\text { 酸化による消費 })
\end{aligned}
$$

$$
\begin{aligned}
& \frac{d B_{\text {sed }}}{d t}=(\text { 植物プランクトンの沈降 }) \\
& \quad+\text { (懸濁態有機物の沈降 }) \\
& \quad-(\text { 好気的分解 })-(\text { 嫌気的分解 })
\end{aligned}
$$

\section{（3）計算格子}

国土交通省千葉港湾事務所の水平 $50 \mathrm{~m}$ 水深デー夕をべ 一スとし，これに佐々木ら（2007）による深浅測量によ って得られた浚渫窪地の水深デー夕を取り达むことで, 改良版の水平 $50 \mathrm{~m}$ 水深デー夕を作成し，これから図-2に 示すような，水平 $450 \mathrm{~m}$ の東京湾全体格子（大領域）を 作成した。次に，この大領域格子から図-2中に示す，浚

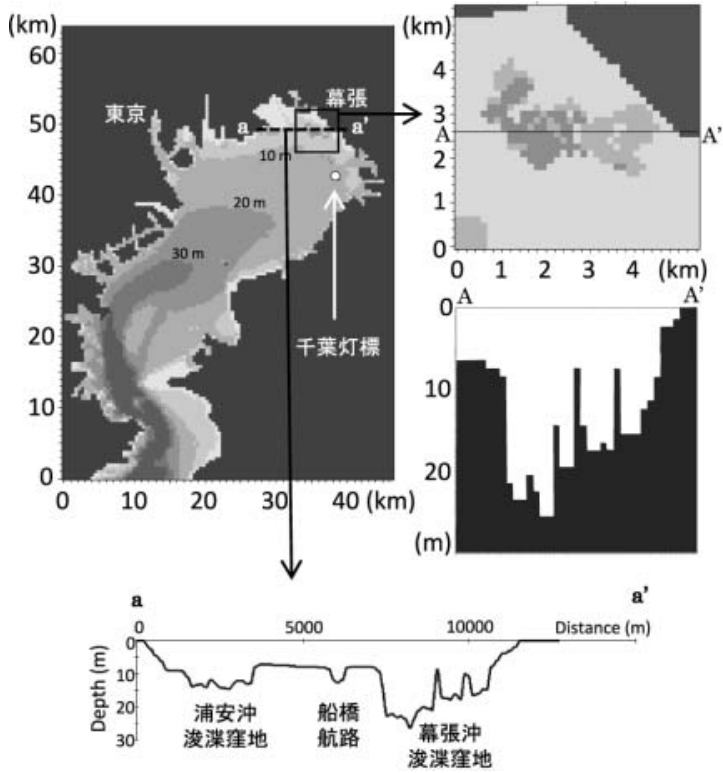

図-2 大領域および小領域の計算格子の概要

渫窪地およびその周辺海域を対象とした，水平 $150 \mathrm{~m} の$ 小領域格子を作成した。両格子とも，鉛直方向には $1 \mathrm{~m}$ 間隔の計30層とした。

\section{（4）再現計算の境界条件}

2007年を対象として, 気象データ, 河川流量, および 湾口潮位等の実測值を入力し再現計算を行った.

それぞれ気象庁の気象統計情報より千葉の観測所で計 測された風速，風向，気温，相対湿度，雲量，および降 水量を，全天日射量は東京の観測所より入手した．河川 流量については，多摩川には調布堰観測值を，江戸川に は江戸川水閘門からの推定放流量を使用した。隅田川, 荒川，鶴見川については多摩川の流量デー夕に比流量倸 数を乗じて算出した。湾口潮位については海上保安庁の リアルタイム験潮デー夕より横須賀の実測潮位デー夕を 入手して与えた。ささに水温, 塩分等の水質項目につい ての湾口部の境界条件および初期条件については, 「2002-2003年東京湾広域環境調査」（高尾ら，2004）を 参考に，湾口境界条件については月平均值を一ヶ月間ご とに与え，初期条件については水平方向・鉛直方向にお いて一様に与えた。計算期間を 2007 年 3 月 1 日から 9 月末 までの期間に設定し，浚渫窪地の詳細な水質変動を計算 するため，水平 $150 \mathrm{~m}$ 格子を用いた小領域を設定し大領 域からのネステイング計算（図-2）を行った。この時の 初期条件として 2007 年 8 月 24 日の窪地に扔ける現地調查 で得られた水質デー夕を初期条件として与えた。

\section{（5）導水のモデル化}

浚渫寉地に扔ける任意の海底格子に，水温，塩分，お よび流量を指定した鉛直上向きのjetを与えることで，導 
水効果を模擬した．検討ケースとしては沖合高密度水の 導水および表層低密度水の導水について検討し, それぞ れ, 無酸素水塊がよく発達し, 水塊が安定していた, 2007 年 8 月 1 日から 8 月 28 日までの 4 週間を対象とした数 值実験を行った。

\section{3. 結果と考察}

\section{（1）東京湾全域の計算と数値モデルの検証}

2007年を対象とした, 東京湾全域における数值シミュ レーションを実施し, 海上保安庁モニタリングポストの 千葉灯標における, 表層および底層の水温, 塩分, およ びDOの時系列結果と併せて, 図-3に示した。計算結果 は全般的には実測デー夕をよく再現しているといえる. 特に成層強度を決定づける水温と塩分の動態については 季節的な変動に加え，例えば，8月下旬から9月初旬には 北東風の影響によって水温低下と塩分上昇が見られ，底 層の水塊が湧昇している様子等, 短時間変動についても ある程度再現されている。一方, DOに着目すると, 夏 季の東京湾においては南風系が卓越しており, 表層水が 湾奥に留まると同時に活発な光合成により DOは飽和状 態となるのに対し, 底層部では恒常的に貧酸素状態とな っている様子が再現されている. また, 水温, 塩分と同 様に, 8月下旬から9月初旬にかけて, 底層水の涌昇によ る表層DOの低下が確認でき, 9 月 5 日から 7 日にかけて 上陸した台風による強風による密度成層の解消によって DOが回復し, 数日後に貧酸素水塊が再形成される過程 についても，計算值は実測值とょく整合しているとい える.

一方, 8 月の水温・塩分場の短時間変動の再現性や表 層 DOの再現性には課題もある. 様々な条件下での数值 シミュレーションの結果, 水温, 塩分の再現性の向上に は, 湾口に扔ける境界条件の高精度化が不可欠であると 推測された. 本シミュレーションでは湾口境界条件とし ては平均的な季節変動を与えているだけであるが，この 与え方が河川流量等の他の条件と比較して, 千葉灯標に おける計算值により大きな影響を与えることが判明して いるため, 内湾のモニタリングの高度化に際しては, 湾 口境界条件の把握が最優先事項であるといえる.

これに対し, 表層DOの再現性については光合成過程 の精密再現に課題があるが, 本研究では底層の筫酸素過 程の再現に主眼をおいているため, モデル全体のバラン スを考えると，現状のままでも十分有効であるものと判 断した.

\section{（2）浚渫窪地における再現計算}

次に，先の大領域計算結果のうち，8月24日を初期条 件とし, さらに現地調査結果から 8 月 24 日の幕張沖浚渫 洼地における水質場の初期条件を与え, 大領域計算結果
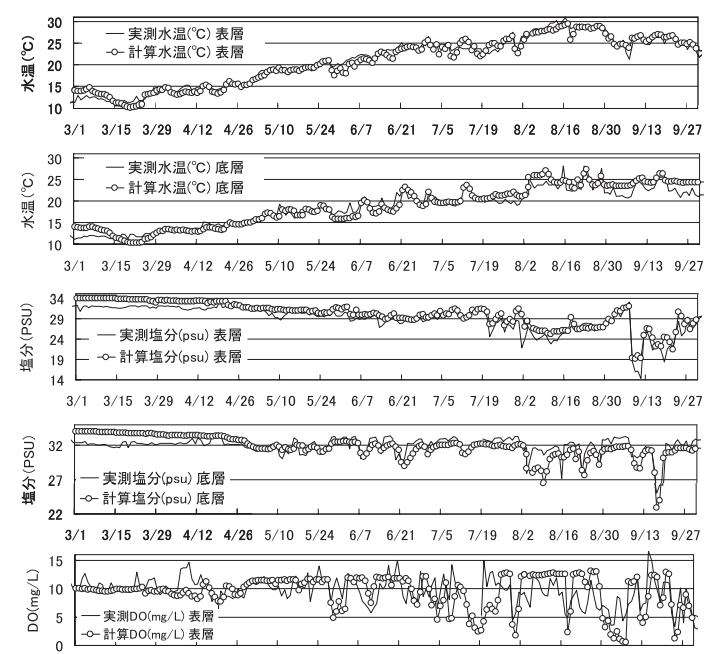

$\begin{array}{llllllllllllllll}3 / 1 & 3 / 15 & 3 / 29 & 4 / 12 & 4 / 26 & 5 / 10 & 5 / 24 & 6 / 7 & 6 / 21 & 7 / 5 & 7 / 19 & 8 / 2 & 8 / 16 & 8 / 30 & 9 / 13 & 9 / 27\end{array}$

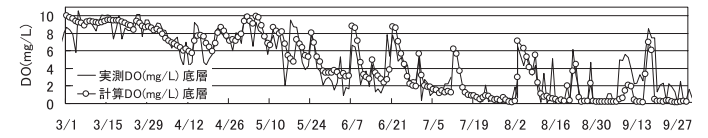

図-3 2007 年の千葉灯標に扔ける表層と底層の水温, 塩分, DO時系列の計算值と実測値の比較

を境界条件として与えながら, 9月末までの浚渫窪地を 含む小領域のone-way ネスティングによる計算を行った. 8 月 31 日および 9 月 20 日の浚渫窪地における, DOおよび 硫化物濃度の鉛直分布の計算值と実測值の比較を図-4に 示す．DOの計算結果を見ると計算值は実測值を概ねよ く再現しているといえる. ただし, 浚渫窪地内に扔いて は両日共に計算值の方が実測值よりやや值が大きくなっ ている。これは数值誤差のため, $\mathrm{DO}=0 \mathrm{mg} / \mathrm{L}$ の值を得る ことが困難であることに加え，DOが負となる場合を許 容していないことから生じるものであり, 硫化物の再現 を担保するようにパラメーターのチューニングを行って いる. 一方, 硫化物に着目すると, 初期条件の 8 月 24 日 には最大 $10 \mathrm{mg} / \mathrm{L}$ 程度であったものが 8 月 31 日には最大で $40 \mathrm{mg} / \mathrm{L}$ 程度に達する様子がある程度再現されている.

さらに9月5日から7日にかけての台風接近時の様子を 含む浚渫窪地内での水質動態を見るため, 図-5および図6にそれぞれ8月31日，9月7日，および9月20日におけ る, 図-2のA-A'鉛直断面におけるDO㧍よび硫化物濃度 分布の計算值を示す. 8 月 31 日には北東風による無酸素 水塊の湧昇が見られ，9月7日には台風接近による中層ま での成層破壞によって, 窪地の無酸素水塊が縮小し, そ の後の比較的穏やかな気象条件の結果として, 9月20日 には再び無酸素水塊が発達する様子が捉えられている. なお，9月7日の台風接近時に抢いても浚渫窪地下層の硫 化物は解消されていないことも確認され, 窪地下層の水 塊が極めて安定したものであることを裏付けている 

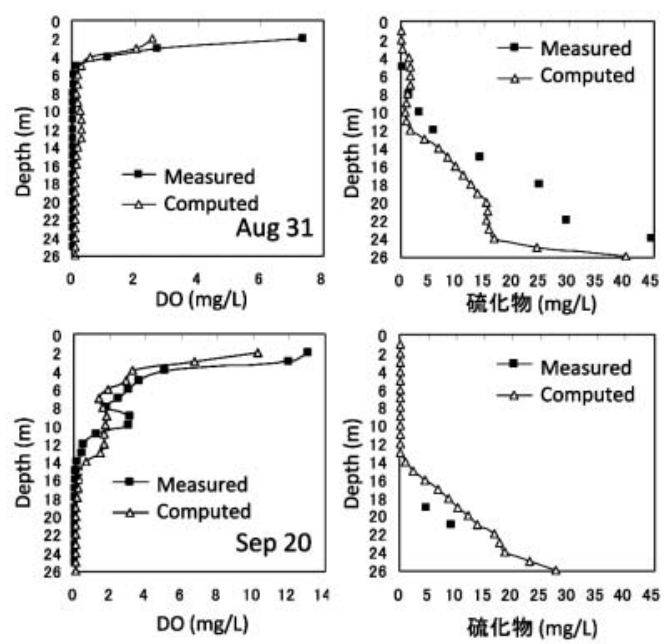

図-4 2007年8月31日抢よび9月 20 日における幕張沖浚渫窪地 におけるDO と硫化物濃度の鉛直分布の計算值と実測値 の比較
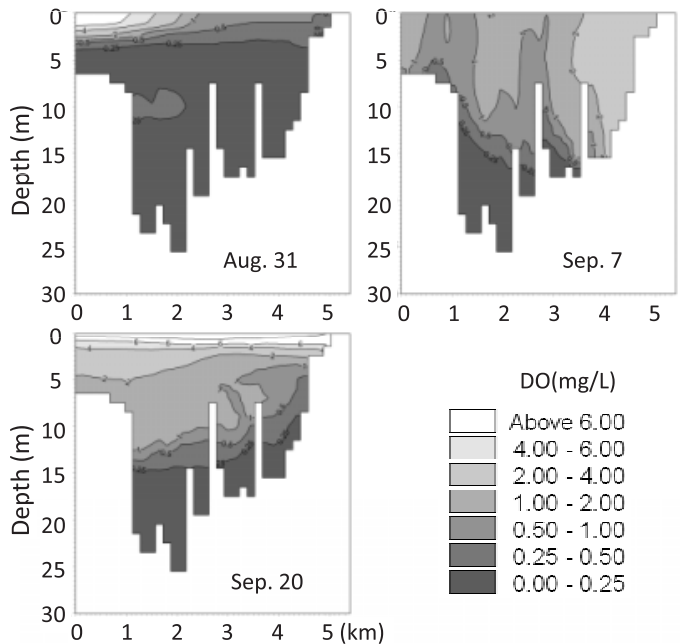

図-5 浚渫窪地におけるDO 断面分布計算值

（佐々木ら，1996；五明ら，1998）.

本研究では準3次元モデルを採用したが，特に浚渫窪 地の流動過程については非静水圧3次元モデルを適用す るのが本来望ましい。一方で, 非静水圧 3 次元モデルは 計算コストが大きく，また，実測值の再現性に基づく議 論を展開する観点からは，境界条件や格子サイズ等，計 算精度に関わる様々な要因があり，それらとのバランス を含め, 検討する必要がある。本研究では実測值との比 較を通し, 準 3 次元モデルに基づく数值シミュレーショ ンでも, 浚渫窪地における水質過程をかなりの精度で再 現可能であることを示したが，両モデルの相違や非静水 圧3次元モデルの活用法については今後の検討課題とし たい.
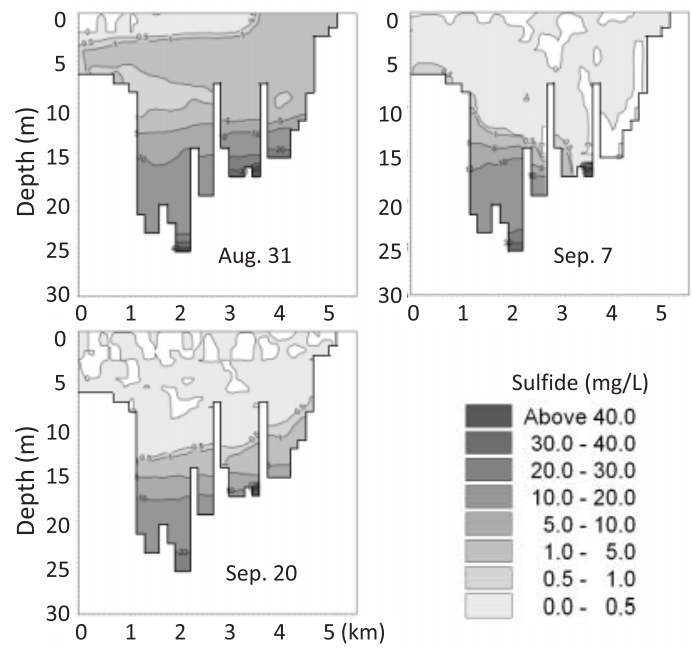

図-6 浚渫寉地に扔ける硫化物濃度断面分布計算值

\section{（3）導水を用いた数值実験}

図-7に，低密度水 1 (水温 $29^{\circ} \mathrm{C}$, 塩分 $27 \mathrm{psu}$ ), 低密度 水 2 (水温 $29^{\circ} \mathrm{C}$, 塩分 $25 \mathrm{psu}$ ), および高密度水（水温 $18^{\circ} \mathrm{C}$, 塩分 $33 \mathrm{psu}$ ) それぞれを海底面 10 格子から合計 50 $\mathrm{m}^{3} / \mathrm{s}$ で導水した場合の，13日後と 28 日後に打けるDOの 鉛直断面分布（図-2のA-A'断面）を示す.

導水無しのケースでは寉地全体に無酸素水塊が発達し ているが，導水を行ったケースではいずれの場合も DO が大きく改善していることが分かる．また，計算開始後 18日目の北東風の連吹によってどのケースも底層部の水 塊が湧昇し, 貧酸素状態が解消されたが, 導水無しのケ 一スでは再び無酸素水塊が形成される様子が再現された。

導水方法の比較では, 窪地底層の無酸素水の改善に関 しては, 高密度水を用いた場合が最も有効であった。こ れは導水した高密度水が寉地底層に留まることで, DO の効率的な改善効果が現れたものである。しかし，高密 度水を導水したケースでは成層構造が維持強化されるた め，導水を中止すると強い成層状態のため，無酸素水塊 の形成を早めてしまうことが示唆された。そのため高密 度水の導水による貧酸素改善に際しては連続運転が不可 欠となる。一方, 低密度水の導水では浮力による連行を 伴う水塊の上昇によって, 䆶地内外での攪拌が起こるが, その効果の程度は導水した海水の密度, 流量, および窪 地の鉛直スケールによって変わってくる.

そこで, 低密度水を導水した 2 ケスを比較すると, より低密度の海水を導水した場合に鉛直混合が促進さ れ，より有効であることが示された。このことは，温排 水を送水することや，できるだけ表層の水をドラフト付 きのメカニカルサーキュレータによって䆶地底層へ送水 することが有効であることを示している. 

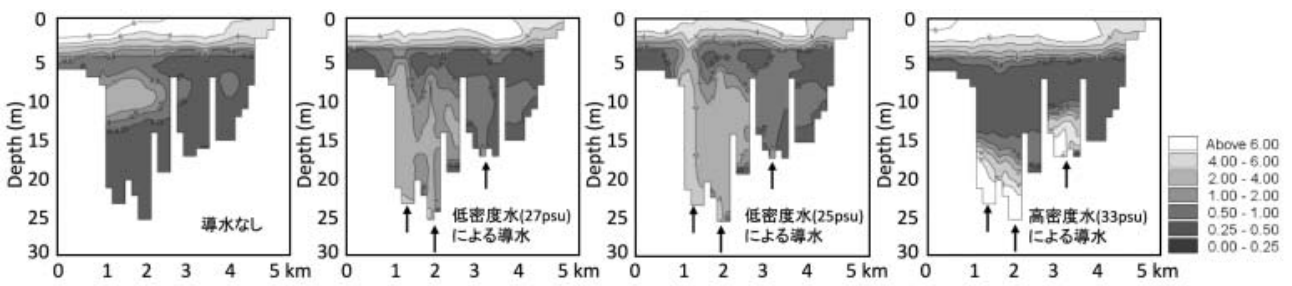

13 日後
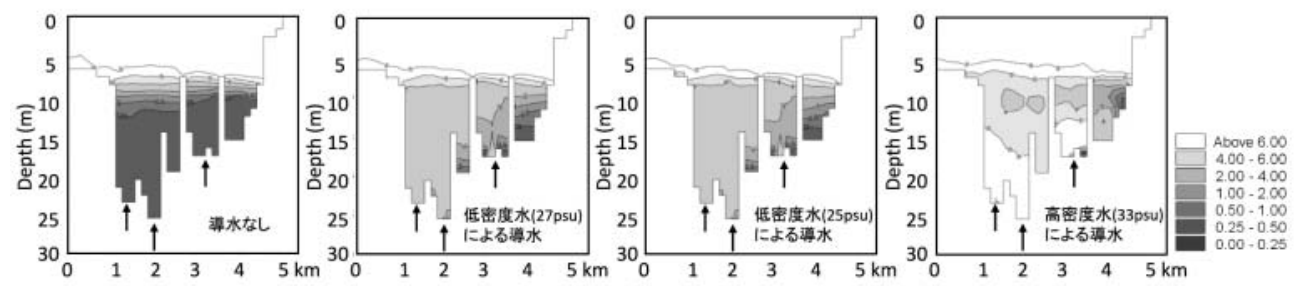

図-7 低密度水および高密度水の導水開始 13 日後および 28 日後におけるDO の断面分布計算值（矢印は導水位置）

さらに低密度水を送水する方法は長期的な運転によっ て成層を弱める働きもあることから，エネルギー効率の 最も高い間欠的な運転方法が存在すると考えられ，これ らを総合して考えると, 低密度水の導水が有利であると 考えられる.

\section{4. 結論}

東京湾幕張沖浚渫窪地を対象として, DOおよび硫化 物濃度の再現を志向した数值モデルを構築し, 実測值と の比較を通してモデルの検証を行った。本モデルを用い て導水を用いた無酸素水の改善手法に関する数值実験を 行ったところ, 高密度水を用いたケースがより効果的で あったが，これは導水した高密度水が窪地底層に留まる ことで, DOの効率的な改善効果が現れたものと理解さ れた。しかし, 高密度水を導水したケースでは成層構造 が維持強化されるため, 貧酸素改善のためには連続的な 運転を要することが分かった。一方, 低密度水の導水で は浮力による水塊の上昇と連行の作用によって, 窪地内 外での攪拌が起こるが, その効果の程度は導水した海水 の密度, 流量, および寉地の空間スケールによって支配 されることが分かった．また，このケースでは成層が弱 められるため, 長期的にはDOの鉛直拡散を促進する方 向に働き, 間欠的な運転, 温排水の利用やドラフトを有 するメカニカルサーキュレータの適用が有効と考えられ ることから, 低密度水の導水が総合的には有利であるこ とが示唆された。
謝辞：本論文で使用したMIKE3 はデンマーク水理環境研 究所（DHI）より横浜国立大学に対し使用を許諾して頂 いた。ここに記し, 謝意を表する。本研究の一部は2007 年度～2010年度日本学術振興会科学研究費基盤研究（B） 課題番号19360220の補助によるものである.

\section{参 考 文 献}

大見智亮 - 内藤大輔 - 酒井 亨 - 山口将人 - 寺澤知彦 - 田口 浩一・中田喜三郎・中村由行 (2008) : 淩渫寉地におけ る酸素環境シミュレーション, 海岸工学論文集, 第 55 巻, pp. 1026-1030.

五明美智男 - 佐々木 淳 ・磯部雅彦（1998）：東京湾湾奥の浚 渫窪地における湧昇現象の現地観測, 海岸工学論文集, 第45巻, pp. 981-985.

佐々木 淳 - 磯部雅彦 - 渡辺 晃・五明美智男（1996）：東 京湾における青潮の発生規模に関する考察，海岸工学論 文集，第43巻，pp. 1111-1115.

佐々木 淳 - 川本慎哉 - 吉本侑矢 - 石井光廣 - 柿野 純 （2007）：東京湾の青潮に及ぼす平場と浚渫窪地水塊の影 響評価, 海岸工学論文集, 第54巻, pp. 1041-1045.

佐々木 淳・佐貫 宏・磯部雅彦（1998）：東京湾における 富栄養現象の再現計算, 海岸工学論文集, 第 45 巻, pp. 1036-1040.

高尾敏幸 - 岡田知也 - 中山恵介 - 古川恵太 (2004）：2002年 東京湾広域環境調査に基づく東京湾の滞留時間の季節変 化，国総研資料，第 169 号，77pp.

田中昌宏・Arjen Markus ・阪東浩造（1997）：青潮の生化学反 応を含む数值モデルの開発, 海岸工学論文集, 第 44 巻, pp. 1096-1100.

中村由行 - 中田喜三郎 - 船越茂雄 - 寺澤知彦 - 今尾和正 （2008）：港湾における発生土砂を利用した㴭渫窪地修復 効果の定量的評価手法の開発, (独法) 鉄道 - 運輸機構 「運輸分野における基礎的研究推進制度」研究報告書, pp. 128-164. 